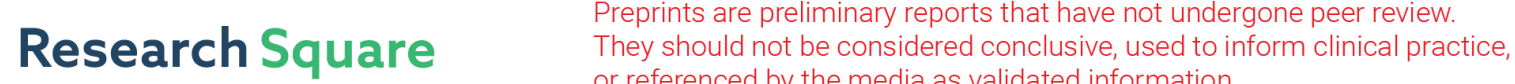 or referenced by the media as validated information. \\ Bayesian Multilevel Analysis of Stunting Status among Children Aged 6-59 Months in Ethiopia
}

Munira Abdulkedir ( $\nabla$ munirahusen88@gmail.com )

Madda Walabu University

Research Article

Keywords: Stunting status, Bayesian Multilevel logistic regression, Ethiopia

Posted Date: January 4th, 2021

DOI: https://doi.org/10.21203/rs.3.rs-120886/v1

License: (9) This work is licensed under a Creative Commons Attribution 4.0 International License.

Read Full License 


\title{
Bayesian Multilevel Analysis of Stunting Status among Children Aged 6-59 Months in Ethiopia
}

\author{
Munira Husen
}

Email address: munirahusen88@gmail.com

Institute: Madda Walabu University, Department of Statistics, Bale Robe Ethiopia

Phone number +25932281480

\begin{abstract}
Background: Stunting is a public health problem that can pose a serious threat to global health because it can lead to less optimal growth and development potential. The aim of this study was to determine the prevalence of stunting and identified the various possible factors associated with stunting status among children aged 6-59 months in Ethiopia by using Bayesian Multilevel Analysis.
\end{abstract}

Methods: The descriptive result revealed that 8640 Children's considered in the analysis, also showed that in Ethiopian Children's who live in Afar and Amhara regions were more than other regions in prevalence of stunting. Bayesian multilevel binary logistic regression of random 3 coefficient models were employed for data analysis based on the selection of smallest value of DIC.

Result: From these models, place of residence, educational attainment of women, husband educational level, sex of child, age of child, Size at birth, body mass index of mothers, household wealth index and birth order are significant factors.

Conclusion: The Bayesian multilevel random coefficients model was better fit than empty and random intercept. The variance of the random component related to the coefficient model was implying regional variations in stunting status of children among the regions in the country.

Keywords: Stunting status, Bayesian Multilevel logistic regression, Ethiopia 


\section{INTRODUCTION}

All nutrient deficiencies have an enormous impact on health. With good nutrition, children develop into healthy, bright and engaged members of their communities; and they are stronger and more resilient in the face of crisis. Today, there are still 50 million young lives at risk due to acute malnutrition; and 156 million more children under the age of 5 years are chronically undernourished or stunted, compromising their physical growth and brain development.

Stunting is a public health problem that can pose a serious threat to global health because it can lead to less optimal growth and development potential (Perkins et al., 2017), and closely related to the risk of death in children under five (Acevedo et al., 2017). Stunting has declined by almost 2 percent annually over the last four years, affecting 7.7 million fewer children in 2016 than in 2013.

In Ethiopia, the trend Shows in the reduction of child under-nutrition between 2000 and 2016. The prevalence of stunting has decreased considerably from 58\% in 2000 to $38 \%$ in 2016, an average decline of more than 1 percentage point per year (CSA, 2016).

Nutrition-specific approach is still important and should be continued and extended especially to low-income households. Although food supplementation and fortification has an important impact, the aspect of complexity emphasized too. Health-based nutrition services in Ethiopia became a priority (UNICEF et al., 2015). This study would like to mention a few with a board impact like education, climate and gender that should be never excluded. 


\section{Data and Methodology}

\section{Data Description}

This study used the data collected in the Ethiopian Demographic and Health Survey (CSA, 2016). The EDHS sample was selected using a stratified, two-stage cluster design and EAs were the sampling units for the first stage. For the 2016 EDHS, a representative sample of approximately 18, 008 households from 645 clusters was selected. In the first stage, 645 clusters, 202 urban and 443 rural, were selected from the list of enumeration areas based on sampling frame. In the second stage, a complete listing of households was carried out in each selected cluster. For this study 8640 children were included in the analysis were the other were missing information.

\section{Statistical Analysis}

In different studies the response variable height-for-age (stunting) measurement status was expressed in Standard Deviation (SD) units (Z-score) from the median of the reference population. Variable category 0 if not stunted $(\geq-2 S D)$ and category 1 if stunted $(<-2 S D)$. In

view of this, the response variable, the status of stunting of the $i^{\text {th }}$ child was measured as a dichotomous variable.

The predictor variables were studied as determinants of stunting status of among children aged and 59 months are grouped into Socio-economic, Demographic, and Health and Environmental factors. These includes age of child, size at birth, birth order, mother education status, father education status, mother working, family size, type of place of residence, wealth index, region, body mass index, source of drinking water, toilet facilities, had diarrhea in the last two weeks, and had fever in the last two weeks.

The multilevel logistic regression analysis considers the variations due to hierarchy structure in the data. In this data structure, level-1 is the Children level and level-2 is the regional level. Within each level-2 unit there are $n_{j}$ in the $j^{\text {th }}$ region. 


\section{Bayesian Multilevel Analysis of Empty Models}

The logit linear predictor is given as:

$\operatorname{logit}\left(\pi_{i j}\right)=\beta_{0}+U_{0 j}$

Where $\pi_{i j}=\frac{e^{\beta_{0}+U_{0 j}}}{1+e^{\beta_{0}+U_{0 j}}}$ and the deviation $U_{0 j}$ are assumed normal distribution with mean zero and variance $\sigma_{0}^{2}$.

Likelihood Function: The key ingredients to a Bayesian analysis are the likelihood function, which reflects information about the parameters contained in the data, and the prior distribution, which quantifies what is known about the parameters before observing data.

The likelihood contribution from the $\mathrm{i}^{\text {th }}$ subject in the $\mathrm{j}^{\text {th }}$ group is Bernoulli: which is given as follows;

$$
L\left(\pi_{i j=Y_{i j}}\right)=\prod_{j} \pi_{i j}^{Y_{i j}}\left(1-\pi_{i j}\right)^{1-Y_{i j}}
$$

Prior Distribution: Prior distribution plays an important role and the basis in Bayesian analysis i.e. one of the pre-condition in Bayesian analysis is the choice of a prior distribution.

The prior distribution for the parameter $\beta_{0}$ and $\sigma_{0}^{2}$ is given as follows:

$P\left(\beta_{O}\right) \sim$ Uniform Distribution

$\mathrm{P}\left(\sigma_{0}^{2}\right) \sim$ inverse-gamma $(\alpha, \theta)$, where $\alpha$ and $\theta$ are fixed constant parameters.

\section{Posterior Distribution:}

After finding the likelihood and prior function, the next step is to find the random parameter of empty model from the posterior distribution of empty model from the posterior distribution $P\left(\beta_{O}, \sigma_{o}^{2} / Y_{i j}\right)$. This is given as follows;

The full conditional distribution for parameter $\beta_{o}$ is. 
$\mathrm{P}\left(\beta_{o} / \sigma_{u}, y_{i j}\right) \propto \prod_{j}\left(\frac{e^{\beta_{o}+u_{o j}}}{1+e^{\beta_{o}+u_{o j}}}\right)^{y_{i j}}\left(\frac{1}{1+e^{\beta_{o}+u_{o j}}}\right)^{1-y_{i j}}$

For the second parameter of $\sigma_{0}$, the full conditional distribution of posterior for parameter from the given likelihood and prior distribution is Follow the gamma distribution. This implies that, the prior is the conjugate prior and the posterior is given as:

$\mathrm{P}\left({ }^{\sigma_{o}} / \beta_{\beta_{o}}, y_{i j}\right) \sim$ inverse- Gamma $(n / 2+n(\alpha-1), n \theta)$

Where $n$ is the Total number of children's interviewed which the sum of $n_{j}$.

\section{Hypothesis:}

$H_{0}$ : There is no regional variation on Stunting Status in Ethiopia.

$H_{1}$ : There is regional variation on Stunting Status in Ethiopia.

\section{Bayesian Multilevel Analysis of Random Intercept Models}

The logit of $\pi_{i j}$ is a sum of linear function of explanatory variables and given as

$\operatorname{Logit}\left(\pi_{\mathrm{ij}}\right)=\log \left[\frac{\pi_{i j}}{1-\pi_{i j}}\right]=\beta_{o j}+\beta_{o j} X_{1 i j}+\cdots+\beta_{k} X_{k i j}=\beta_{o j}+\sum_{h=1}^{k} \beta_{h} x_{h i j}$

where the intercept term $\beta_{0 j}$ is assumed to vary randomly and is given by the sum of an average intercept $\beta_{0}$ and group-dependent deviations $U_{0 j}$, that is $\beta_{0 j}=\beta_{0}+U_{0 j}$ as a result.

$$
\operatorname{logit}\left(\pi_{i j}\right)=\beta_{0}+\sum_{h=1}^{k} \beta_{h j} x_{h i j}+U_{0 j}
$$

where $\beta_{0}+\sum_{h=1}^{k} \beta_{h j} x_{h i j}$ is the fixed part of the model and $U_{0 j}$ is the random part.

The $\pi_{i j}$ is given as:

$$
\pi_{i j}=\frac{e^{\beta_{0}+\sum_{h=1}^{k} \beta_{h j} x_{h i j}+U_{0 j}}}{1+e^{\beta_{0 j^{+}} \sum_{h=1}^{k} \beta_{h j} x_{h i j}+U_{0 j}}}
$$


For the prior and posterior distribution it is the same as in equation (3) and (4) above except the number of parameter are larger in Bayesian Multilevel Random Intercept model.

\section{Bayesian Multilevel Analysis of Random Coefficient Models}

Consider a model with group specific regression of logit of the success probability logit $\left(\pi_{i j}\right)$, on a single level -one explanatory variables $\mathrm{x}$.

$$
\operatorname{logit}\left(\pi_{i j}\right)=\log \left[\frac{\pi_{i j}}{1-\pi_{i j}}\right]=\beta_{0}+\sum_{h=1}^{k} \beta_{h} x_{h i j}+U_{0 j}+\sum_{h=1}^{k} U_{h j} x_{h i j}
$$

The term $\sum_{h=1}^{k} U_{h j} x_{h i j}$ can be regarded as a random interaction between group and the explanatory variables. The deviation $U_{h j}$ are assumed normal distribution with mean zero and variance covariance matrix $\Omega$. This model implies that the groups are characterized by two random effects: their intercepts and their slopes. It assumes that, for different groups the pairs of random effects $\left(U_{0}, U_{h j}, \mathrm{~h}=1,2, \ldots, \mathrm{k}\right)$ are independent and identically distributed. The random intercept variance, $\operatorname{Var}\left(U_{0 j}\right)=\sigma_{0}^{2}$, the random slope variance, $\operatorname{Var}\left(U_{1 j}\right)=\sigma_{1}^{2}$ and the covariance between the random effects, $\operatorname{Cov}\left(U_{0 j}, U_{1 j}\right)=\sigma_{01}^{2}$ are called variance components (Snijders and Bosker, 1999).

\section{Likelihood Function}

$$
\left(y_{i j} / \pi_{i j}\right) \propto \operatorname{Bernoulli}\left(\pi_{i j}\right)
$$

Let us denote the likelihood function like $L\left(y_{i j}, \pi_{i j}\right)$ and written as follows;

$L\left(\pi_{i j / Y_{i j}}\right)=\prod_{i j}\left(y_{i j} / \pi_{i j}\right)$ and the linear predictor or the logit function is, 


$$
\begin{gathered}
\operatorname{logit}\left(\pi_{i j}\right)=\log \left[\frac{\pi_{i j}}{1-\pi_{i j}}\right]=\beta_{0 j}+\sum_{h=1}^{k} \beta_{h j} x_{h i j}+U_{0 j}+\sum_{h=1}^{k} U_{h j} x_{h i j}, \\
\text { Where, } \pi_{i j}=\frac{e^{\beta_{0 j^{+}} \sum_{h=1}^{k} \beta_{h j} x_{h i j}+U_{0 j}+\sum_{h=1}^{k} U_{h j} x_{h i j}}}{1+e^{\beta_{0 j^{+}} \sum_{h=1}^{k} \beta_{h j} x_{h i j}+U_{0 j}+\sum_{h=1}^{k} U_{h j} x_{h i j}}}
\end{gathered}
$$

\section{Prior Distribution}

Let us denote the parameters $\beta_{0}, \beta_{1}, \ldots \ldots \ldots \beta_{k}$ and $\Omega_{u}$ as prior distribution as follows.

$\mathrm{P}\left(\beta_{0}\right) \propto 1, \mathrm{P}\left(\beta_{1}\right), \ldots \ldots \ldots \ldots \mathrm{P}\left(\beta_{k}\right) \propto 1$ and $\mathrm{p}\left(\Omega_{u}\right) \sim$ inverse-Wishart $\left(s_{u}, \mathrm{~h}\right)$ distribution. Where $\Omega_{u}$ is the variance covariance matrices, $s_{u}$ is an estimate for the true value of $\Omega_{u}$, k is dimension of $\Omega_{u}$, is the parameter that denotes the degree of freedom, so this prior is essentially as uninformative prior. In statistics, Wishart distribution is a generalization to multiple dimensions of the chi-squared distribution, or, in the case of non-integer degrees of freedom, of the gamma distribution (Steven W. Nydick, 2012). The Wishart distribution is the sampling distribution of the matrix of sums of squares and products of normal distributional assumption.

Then $\Omega_{u}$ is positive definite with probability density function is given by:-

$\mathrm{f}\left(\Omega_{u}\right)=\frac{|s|^{\frac{h}{2}}}{|\Omega|^{\frac{h+p+2}{2}} 2^{\frac{h k}{2}} \operatorname{gamma}(k)^{\frac{h}{2}}} \exp \left\{-\frac{1}{2} \operatorname{tr}\left(s^{-1} \Omega\right)\right\}$

\section{Posterior Distribution}

Using the above prior and likelihood function above the the full conditional distribution of posterior parameter $\beta_{0}, \beta_{1}$, , is given by:

$$
P\left(\mathrm{~B}_{\mathrm{h}} /_{\Omega_{\mathrm{u}}}, \mathrm{U}_{\mathrm{oj}}, \mathrm{Y}_{\mathrm{ij}}\right) \propto \prod_{\mathrm{ij}}\left(\left(\pi_{\mathrm{ij}}^{\mathrm{yij}}\left(1-\pi_{\mathrm{ij}}\right)^{1-\mathrm{yij}}\right)\right.
$$

Where $\mathrm{h}=1,2, \ldots \ldots ., \mathrm{k}$ and

$$
P\left(\Omega_{\mathrm{u}} / \mathrm{B}_{\mathrm{h}}, \mathrm{U}_{\mathrm{oj}}, \mathrm{y}_{\mathrm{ij}}\right) \propto \mathrm{P}\left(\mathrm{y}_{\mathrm{ij}} / \Omega_{\mathrm{u}}, \mathrm{B}_{\mathrm{h}}, \mathrm{U}_{\mathrm{oj}}\right) \mathrm{P}\left(\mathrm{U}_{\mathrm{oj}} / \Omega_{\mathrm{u}}\right) \mathrm{P}\left(\Omega_{\mathrm{u}}\right)
$$




\section{RESULTS AND DISCUSSION}

\section{Descriptive Results}

The association between stunting status of children aged 6-59 months and predictors shown from Table 1 indicates that stunting was strongly associated with region, family size, wealth index, sex of child, age of child, place of residence, body mass index of mother, size at birth, 
birth order, mother's educational level, father's educational level, mother's employment status, had diarrhea in the last two weeks and had fever in the last two weeks.

Also from Table 1 result the association of response variable for each predictor, a test of association was carried out using the chi-square at 5\% level of significance. The hypothesis testing is: $\mathrm{H}_{0}$ : There is no association between the response variable and each predictor $\mathrm{Vs}_{\mathrm{H}}$ : There is an association between response variable and each predictor. Accordingly, the chisquare association between Stunting Status of among aged 6 and 59 months and each predictors.

In the multilevel analysis, a two-level structure is used with regions as the second-level units and Children as the first level units. This is basically with the expectation that there would be a difference in Stunting Status among regions. The nesting structure is Children within regions with a total of 8640 respectively.

\section{Bayesian Multilevel Logistic Regression of Empty model}

From the results presented in the from Table 2 above show that overall mean of Stunting Status is estimated at $\beta_{o}=3.722$ respectively and significant.

Here the null hypothesis tested is $\sigma_{0 j}=0$. i.e., there is no regional variation in Stunting Status in Ethiopia. Based on the from Table 2 result the values are significant at 5\% significance level and the null hypothesis has to be rejected, indicating strong evidence that the between region variance is non zero. The variance of the random factor is significant which indicates that there are regional differences in Stunting Status and thus, multilevel analysis can be considered as an appropriate approach for further analysis. 


\section{Bayesian Multilevel Logistic Regression Random Intercept Model}

From the result of Bayesian Multilevel Random intercept model from Table 3 understood that the random part is the intercept only having many covariates. The result shows that, the variance of the random factor is significant which indicates that there are regional differences in Stunting Status in the data set. The covariate, Women education level, husband education level, Body mass index, Sex of child, Size of child at birth, Birth order, mother working status, age of Children, wealth index, place of residence was significant, but Had Dirrhea in the last two weeks and Had fever in the last two weeks was not significant.

\section{Bayesian Multilevel Logistic Regression of Random Coefficient Model}

From the output of the random coefficient Bayesian multilevel model presented from Table 4 below, we interpret the results as follows. Some of the independent variables were found to be significant on the stunting status among 6 and 59 month in Ethiopia these are;-Women educational level, father educational level, Body mass index, sex of child, size of child at birth, birth order, employment status of mother, age of children, wealth index and place of residence.

Accordingly, the test statistics explored that family size, had diarrhea in the last two weeks, and had fever in the last two weeks is the only explanatory variables that are found to be insignificant ( $p>0.05$ ) factors of the dependent variables among the considered explanatory variables. The interpretation of the odds ratio for multilevel logistic regression model has no difference from the interpretation in logistic regression model. But the difference between them is the multilevel logistic regression model is additional information than single level regression model, which are they include additional term which is called the random part.

The stunting status among children aged between 6 and 59 months whose mothers have secondary educational level was $72.3 \%$ less likely than children whose mothers have no educatio nal level $\exp (-1.282)=0.277$. Likewise, the odds of stunting status among children aged between 6 and 59 months father who had primary educational level was $\exp (-3.644)=0.026$ this means 97.4\% less likely than Children whose fathers had no educational level. Meaning that children from father who had educational levels were primary, secondary and higher level was less likely to be stunted than children from fathers who had no education. 
In addition, body mass index of mother is a significant factor on stunting of child at $5 \%$ level of significance. The odds of body mass index of mother categories of normal body mass index were $\exp (-1.539)=0.215$. This means that $78.5 \%$ less likely stunting status of child than children from mother who had thin body mass index.

Another finding of this study from Table 4 below indicate that birth order is significant factor on stunting of children among aged 6 and 59 month at $5 \%$ level of significance. The odds of birth

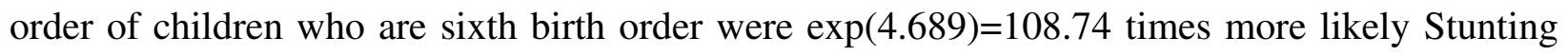
Status among aged 6 and 59 month than first order and the odds Ratio of children between 2-3 birth order and 4-5 birth order were $\exp (2.745)=15.565$ and $\exp (3.456)=31.689$ times more likely stunting status of child than children that first order, respectively. This indicates that children born there after are more likely to be stunted when compared with first order.

On the other hand, Children aged between 6 and 59 months whose mother have employed were $\exp (3.982)=53.624$ times more likely to be stunted when compared to children whose mothers have Unemployed. Similarly, for the categorical variable sex of child, the odds of female children is $\exp (-0.424)=0.654$, which means that the stunted status of female children aged between 6 and 59 month is $34.6 \%$ less likely than male child.

As it indicated in Table 4, The odds of stunting status children with age between 12-23 months was $\exp (2.423)=11.28$ times more likely than the risk of stunting status of children aged between 6-11 months and the odds ratio of stunting status aged between 6 and 59 month children with aged between $24-35$ months was $\exp (-2.423)=0.089$ this means that $91.1 \%$ less likely to be stunted status of children than aged between 6-11 months and the odds of stunting status for children 48- 59 months were $\exp (-3.125)=0.044$. This indicate that 95.6 less likely than the stunting status from the reference (6-11 months).

The odds of stunting status among children aged between 6 and 59 months, those from middle and rich families was $\exp (-1.136)=0.321$ and $\exp (-0.976)=0.377$ respectively, means that $67.9 \%$ and $62.3 \%$, less likely stunted status of child compared to those from poor families. likewise, a variable of place of residence the odds of stunting status of child who living in the rural areas being that children aged between 6 and 59 month was $\exp (1.097)=2.995$ times more likely than stunting status of child who living in Urban area. 
In Table 4 shown, the value of $\operatorname{var}\left(u_{0 j}\right)$ and $\operatorname{var}\left(u_{11 j}\right)$ are the estimated variance of intercept, slope of Size at birth a region wise intercepts and the slopes vary significantly, that is, there is a significant variation in the effects of these explanatory variables across the regions. Since the estimated regional variance $\sigma_{u 0 j}^{2}$ was estimated as 93.737. Here the null hypothesis tested was $\sigma_{u 0 j}^{2}=0$. i.e. there was no regional variation in stunting status of among age 6 to 59 month in Ethiopia versus the alternative hypothesis there was regional variation in stunting status of among age 6 and 59 month in Ethiopia.

In view of the fact that their p-value is less than 0.05 , the null hypothesis has to be rejected, indicating that the variance of the random factor is significant which means that there were regional variations in stunting status among of children among aged 6 and 59 month. Also

estimated variance of slope of size at birth was $\sigma_{u 11 j}^{2}=60.574$, Here the null hypothesis tested was $\sigma_{11 j}^{2}=0$. (There no is significant variation in the effects of these explanatory variables across the regions). Versus the alternative there was a significant variation in the effects of these explanatory variables across the regions. Since their p-value is less than 0.05 , the null hypothesis has to be rejected, indicating that the variance of the random factor is significant which means that there was a significant variation in the effects of these explanatory variables across the regions.

The correlation matrix contains the estimated correlation between random intercepts and the random slopes. Positive correlation between intercepts and slopes implies that regions with higher intercepts tend to have on average higher slopes. The negative sign for the correlation bet ween intercepts and slopes implies that regions with higher intercepts tend to have on average lower slopes on the corresponding predictors.

\section{Model Comparison and Model Fit}

From Table 5 Shown that, the deviance information criteria are the sum of Dbar and pD. So, to compare the models using DIC when we see the DIC (deviance information criteria) diagnostics of Bayesian multilevel logistic regression for random intercept model with the fixed explanatory variables is reduced by 333.85 from that of Bayesian multilevel logistic regression for the null model. So, this Bayesian multilevel logistic regression of random intercept model with the fixed 
explanatory variables is a highly significant improvement suggesting that this model is better than Bayesian multilevel for the null model and the DIC diagnostics of Bayesian multilevel logistic regression of random coefficient model is reduced by 343.57 and 9.72 from Bayesian multilevel logistic regression for random intercept model with the fixed explanatory variables and null model respectively.

Therefore, this smallest values of Bayesian deviance information criteria indicates that Bayesian multilevel logistic regression for random coefficient model is better fits the data to predict stunting status among children aged between 6 and 59 months in Ethiopia. It is also an indication of focusing the Bayesian multilevel logistic regression for random coefficient model.

\section{Assessment of Model Convergence}

From Figure below show the convergence of the fifth parameter (coefficient for mother education and Birth Order) in the surveys. From both figures, 1 and 5 the time series plot looks like horizontal band at 30,000 Iteration. It confirms that the chains are converged. The kernel graphs in both figure 4 and 8 also shows that the coefficient has no bimodal density and it also shows convergence in the surveys. The high mixing within the chain in both figures 2 and 6 also show that high convergence to posterior distribution on ACF. As the number of iteration increased the MSE was decreased as we have seen from both figures 3 and 7 it also shows convergence. 


\section{Discussion}

This study attempted to determine the socio-economic, demographic, and health related factors stunting status among age 6 and 59 month in Ethiopia using 2016 EDHS data. Accordingly, descriptive method and Bayesian Multilevel logistic regression were used in analyses. The Bayesian multilevel logistic regression empty model, the Bayesian multilevel logistic regression random intercept model and Bayesian multilevel logistic regression random coefficient model were used in this study. From the result of model adequacy or goodness of fit of the model using deviance information criteria, Bayesian multilevel logistic regression random coefficient model was identified and this study confirms with the findings in (Tizazu Bayko, 2014)

At first the study included fourteen predictor variables that were categorized under socioeconomi c, demographic and environmental proximate variables. In this analysis Children are considered as nested within the various regions in Ethiopia. In order to explain regional differences in stunting of child, we employed three multilevel linear regression models for response variable.

The results of Bayesian multilevel logistic regression for random coefficient model, educational attainment of mother, educational attainment of father, body mass index, sex of child, size at birth, birth order, employment status of mother, wealth index, age of child, place of residence, were significant factor on stunting status of children among age 6 and 59 month.

Place of residence was significant association with stunting status of child. This shows that Children who are living in rural areas were more likely to be stunted than living in urban areas. This difference might be due to the fact that the resulting in insufficient food production and lack of education about children health, therefore stunting of child in urban area is less than in rural areas. This finding is related with the finding by (TesfahunYonasat el., 2016).

Another determinant factor was educational attainment of mother. These variables were significant contributions on stunting status of child among aged 6 and 59 month at 5\% level of significance. Children whose mother have primary education level, secondary education levels and higher education level less stunting status of child among age 6 and59 month than children whose mother have non education. This indicate that the nutritional status of children is dependent on maternal education and occupation and socioeconomic status, since education 
gives women a sense of empowerment and confidence to make decisions regarding their health and that of children(Eugenie W. and H. Maiga). This result was in line with the result by (Osamor\& Grady, 2016), (NNP \$ Sebastian Vollmer, 2016), (Nkurunziza et al., 2017) and (Belete Adelo, 2014 and Gautam SK, 2018).

Another determinant factor were sex of child, this variables were significant contributions on stunting of child among aged 6 and 59 month at 5\% level of significance. Male child have more likely stunting status than female child. This could be due to genetic differences between male and female children and, due to girls' greater access to food through their gender-ascribed role in contributing to food preparation (Gautam SK, 2018). This Finding agrees with other studied by (Akombi, B. J, 2017) and (MandefroAsfaw, 2015).

The study showed that, Size of child at birth has significant contributions on stunting of child at $5 \%$ level of significance. Smaller than average Size of child at birth more likely stunting than average at birth and larger than average at birth. This result is also similar reported from other study (Indria GA et al., 2016) this study conducted that stunting was positively affected by low birth weight and similarly agree with study by (Ahmed, 2017) as well as reported from (who,2017).

Maternal employment is another determinant of Stunting of child between aged 6 and 59 month and found significantly associated with maternal employment. This means children whose mothers have job are more stunted than children who are non-employed mothers. In other way it have negative effects on the nutritional status of children as it decrease mothers' time spent for their children's caring, feeding and breastfeeding and increases care(Hiwot Esheteet al., 2017). This result was in line with the finding by (Airinet al., 2019)and (Tehsil TakhtBhai, 2017) conducted that Children whose mothers are house wife, the prevalence of Stunting is very low as compare to the children whose mothers are working.

The study showed that Age of child is important determinant factor on stunting of child and positive effect. This indicate that age of a child whose age is 12-23 month is more likely stunted than aged 11-23, 24-35, and 48-59. This might be due to in many such settings, prevalence starts to rise at the age of about three months; the process of stunting slows down at around three years of age, after which mean heights run parallel(F. Habyarimana, 2016). In other ways for children 
under age 5 sharply increases between age 6 and 23 months, and peaks at age 24- 35 months; this represents the impact of under-nutrition in the first 1,000 days of life (EDHS, 2016). This finding is similar from the finding studied by, (Domisiano K. Mwabuet al., 2017).

\section{Conclusions}

The purpose of this study was to identify the determinant of stunting status and to assess regional variation of stunting status among children aged 6-59 months in Ethiopia by using Bayesian Multilevel logistic regression Analysis. This study shown, from the three Bayesian multilevel models, the Bayesian multilevel analysis of random coefficient is preferable since it had smaller Bayesian deviance information criteria than that of empty and random intercept model. The variance of the random component related to the constant term and slope of Size of child at birth were found to be statistically significant, which implies that there is variation in stunting status of children among the regions.

The study Identify some socio-economic and demographic determinant of stunting of child among aged 6 to 59 month. Educational level of mother, educational level of fathers, Sex of child, Size at Birth, body mass index of mothers, birth order, and employment status of mothers, Age of child, Wealth index and place of residence were the significant factor of stunting status of child among aged 6 and 59 month in Ethiopia.

Educational level of women and their husbands are one of the determinant factors of the stunting status of children among aged 6 and 59 month. As education level of mothers and fathers increase the opportunity children are affects by stunting is decreasing. Male children are most likely stunting of child than male children. Again the stunting of child high in smaller than average at birth than average at birth and larger than average at birth.

The amount of stunting high those children whose mother have thin body mass index than normal body mass index and overweight body mass index. In case of birth order there is high stunting in the sixth birth order than 1st, 2-4 and 4-5 birth order. The amount of stunting is high in child whose mothers have employment than unemployment. Again the stunting of children among aged 6 and 59 month high in age group of 12-23. 
The economic status of the household was significantly associated with the Stunting of child rich household were less likely stunting status of child than middle wealthindex household and poor wealth index household. yet again stunting status of children among aged 6 and 59 month high in rural area than urban area.

\section{Declarations}

Ethics approval and consent to participate Not applicable in manuscript

The Data taken from Ethiopian Demographic Health Survey.

Consent for publication Not applicable in manuscript

Availability of data and material Not applicable in manuscript

Competing interests

The authors declare that they have no any competing interests

\section{Authors'contributions}

$\boldsymbol{M H}$ developed the strategy for the review, screened titles and abstracts, conducted the quality assessment, supported data extraction, contributed to the writing of the manuscript, undertook data extraction, conducted the quality assessment, performed the meta-analysis and contributed to the writing of the manuscript. All things can be done by these authors.

\section{Acknowledgments}

The author would like to thank Hawasa University for financial supports for this research, and I want to thanks Ethiopian Demographic Health Survey for allowing me to use the data used in this study.

\section{Author details}

I am Munira Husen, lecturer at Madda Walabu university school of natural and computational science department of statistics in Ethiopia 


\section{REFERENCE}

Abdulahi, A., Shab-Bidar, S., Rezaei, S., \& Djafarian, K. (2017). Nutritional status of under five children in Ethiopia: a systematic review and meta-analysis. Ethiopian journal of health sciences, 27(2), 175-188.

Adelo, B., \& Temesgen, S. (2015). Undernutritional Status of Children in Ethiopia: Application of Partial Proportional Odds Model. Turkiye Klinikleri Journal of Biostati sti cs, $7(2)$.

Aggarwal, T., \& Srivastava, S. (2017). Nutritional status and its correlates in under five children of labour population in urban slums of Lucknow, Uttar Pradesh, India. Int J Contemp Pediatr, 4, 1253- 8 .

Ahmadi, D., Amarnani, E., Sen, A., Ebadi, N., Cortbaoui, P., \& Melgar Quiñonez, H.(2018). Det erminants of child anthropometric indicators in Ethiopia. BMC public health, 18(1), 626.

Alemu, M, Nilola.J, Bekele.T. (2015). Tackling Child Malnutrition in Ethiopia. An international Study of Childhood Poverty.

Ali, A. M., Batu, M. M., \&Kaushik, K. K. (2016). Socio-economic determinants of nutritional status of children in Ethiopia. Int J Sci Res Publications, 6(3), 166-76.

Asfaw, M., Wondaferash, M., Taha, M., \&Dube, L. (2015). Prevalence of under nutritionand associated factors among children aged between six to fifty nine months in Bule Hora district, South Ethiopia. BMC Public health, 15(1), 41.

Behrman, J., \&Hoddinott, J. (2001). An evaluation of the impact of PROGRESA on child height. International Food Policy Research Institute, Washington, DC.

Bender, D. (2014). An introduction to nutrition and metabolism. CRC Press.

Black, R. E., Victora, C. G., Walker, S. P., Bhutta, Z. A., Christian, P., De Onis, M., ... \& Uauy, R. (2013). Maternal and child undernutrition and overweight in low-income and middleincome countries.The lancet, 382(9890), 427-451. 
Blössner, M., De Onis, M., \&Prüss-Üstün, A. (2005). Malnutrition: quantifying the health impact at national and local levels.

Burchi, F. (2012). Whose education affects a child's nutritional status? From parents' to household's education. Demographic Research, 27, 681-704.

Bushie, B. (2004). Determinants of Child Stunting in Urban Ethiopia.Unpublished Msc Thesis. AAU, June.

Chávez-Zárate, A., Maguiña, J. L., Quichiz-Lara, A. D., Zapata-Fajardo, P. E., \&Mayta- Tristán, P. (2019). Relationship between stunting in children 6 to 36 months of age and maternal employment status in Peru: A sub-analysis of the Peruvian Demographic and Health Survey. PloS one, 14(4), e0212164.

Christiaensen, L. and Alderman, H. (2004). Child Malnutrition in Ethiopia: can maternal know ledge augment the role of income: Economic Development and Cultural Change, 52(2):287-312.

CSA: Central Statistics Agency. Population projection (2012) according to the Ethiopia CIA. (2010).The World Fact book: Ethiopia. 2007:

Delgado Sa'nchez HD,Tuesta Dorado P, Valqui Gatica IA (2015) Factores Maternos Asociados al Riesgo de Desnutrición Morona Cocha, Iquitos Peru. Tesis licenciatura, Universida N acional dela Amazonı'a Peruana.Availablefrom:http://dspace.unapiquitoedu.pe/bitstream/ unapiquitos/310/1/tesis.pdf

Duffield, A. (2006). Wealth, health and knowledge: Determinants of malnutrition in North Wollo, Ethiopia. Save the Children, UK.

EDHS (2011). Ethiopian Demographic and Health Survey Central Statistics Agency, AddisAbab a, Ethiopia .https://www.cia.gov/library/publications/theworldfactbook/geos/et.ht m 1.Census

Fotso, J. C., \&Kuate-Defo, B. (2005). Measuring socioeconomic status in health research ndeveloping countries: should we be focusing on households, communities or both. Social Indicators Research, 72(2), 189-237. 
Garti, H., Ali, Z., \&Garti, H. A. (2018). Maternal daily work hours affect nutritional status of children in Northern Ghana. Nutrire, 43(1), 16.

Genebo, T., Girma, W., Haider, J., \&Demissie, T. (1999). The association of children's nutritional status to maternal education in Zigbaboto, Guragie Zone, Ethiopia. Ethiop. J. Health Dev., 13(1)), 55-61.

Getahun, Z., Urga, K., Genebo, T., \&Nigatu, A. (2001). Review of the status of malnutritin and trends in Ethiopia. Ethiopian Journal of Health Development,15(2), 55-74.

Girma, W., \&Genebo, T. (2002). Determinants of nutritional status of women and children in Ethiopia.

Habyarimana, F. (2016). Key determinants of malnutrition of children under five years of ag in Rwanda: Simultaneous measurement of three anthropometric indices. African Population Studies, 30(2).

Hiwot Yisak1, TesfayeGobena and FirehiwotMesfin(2016).Prevalence and risk factors for under-nutrition among children under five at Haramaya district, Eastern Ethiopia.

Hosmer, W.D. and S. Lemeshow (2000). Applied Logistic Regression. 2nd Ed., John Wiley and Sons, New York.

Kavle, J., Mehanna, S., Saleh, G., Foaud, M., Ramzy, M., Hamed, D., ...\& Galloway, R. (2014). Examining factors associated with stunting in lower Egypt in comparison to upper Egypt. Bridging the gap between cultural beliefs and feasible feeding practices through Trials for Improved Practices.

Kikafunda, J. K., Walker, A. F., Collett, D., \&Tumwine, J. K. (1998). Risk factors for early childhood malnutrition in Uganda. Pediatrics, 102(4), e45-e45.

Kusi, A., Enemark, U., Hansen, K. S., \& Asante, F. A. (2015). Refusal to enrol in Ghana's National Health Insurance Scheme: is affordability the problem?.International journal for equity in health, 14(1), 2. 
Lewit, E. M., \&Kerrebrock, N. (1997). Population-based growth stunting. The Future of Children, 149-156.

Maïga, E. W. (2013). The impact of mother's education on child health and nutrition in developing countries: evidence from a natural experiment in Burkina Faso. In African Economic Conference.

Manzione, L. C., Kriser, H., Gamboa, E. G., Hanson, C. M., Mulokozi, G., Mwaipape, O., \& West, J. H. (2019). Maternal Employment Status and Minimum Meal Frequency in Children 6-23 Months in Tanzania. International Journal of Environmental Research and Public Health, 16(7), 1137.

Mason, P., \& Lang, T. (2017). Sustainable diets: How ecological nutrition can transform consumption and the food system. Routledge.

MOFED (Ministry of Finance and Economic Development). (2013). Development and Poverty in), Ethiopia 1995/96-2010/11.Addis Ababa, Ethiopia

Morteza, S., Shokouh, H., Arab, M., Emamgholipour, S., Rashidian, A.,Montazeri, A., \&Mosiur, R., Golam, M., \&Nasrin, S. O. (2009). Nutritional status among children aged 245months in rural Bangladesh: an assessment measured by BMI index. Internet Journal of Biological Anthropology, 3(1).

Negash, C., Whiting, S. J., Henry, C. J., Belachew, T., \& Hailemariam, T. G. (2015). Association between maternal and child nutritional status in Hula, rural Southern Ethiopi A cross sectional study. PloS one, 10(11), e0142301.

Nkukwana, T. T. (2018). Global poultry production: Current impact and future outlook on the South African poultry industry. South African Journal of Animal Science, 48(5), 869 884.

Olivieri, F., Semproli, S., Pettener, D., \&Toselli, S. (2008). Growth and malnutrition of rural Zimbabwean children (6-17 years of age). American Journal of Physical Anthropology: The Official Publication of the American Association of Physical Anthropologists 136(2), 214-222. 
Olofin, I., McDonald, C. M., Ezzati, M., Flaxman, S., Black, R. E., Fawzi, W. W., \& Nutrition Impact Model Study (anthropometry cohort pooling. (2013): Associations of su boptimal growth with all- cause and cause-specific mortality in children underfive years: a pooled analysis of ten prospective studies. PloS one, 8(5), e64636.

Oyekale, A. S. (2017). Microeconometric modeling in applied economic research: the pains, pitfalls and paradoxes.

Oyekale, A. S.andOyekale, T. O. (2000). Do Mother's Education Levels Matter in Child Malnutrition and Health Outcomes in Gambia and Niger, Department Agricultural Economic, University of Ibadan, Nigeria.

Phiri, T. (2014). Review of Maternal Effects on Early Childhood Stunting

Ramos C V., Dumith SC, Cesar JA (2015) Prevalence and factors associated with stunting and excess weight in children aged $0-5$ years from the Brazilian semi-arid region. J Pediatr (Rio J) 91, Suppl. 2, 17582. Available from: http://ac.elscdn.com/S0021755714 001557/1-s2.0-S0021755714001557-main.pdf? tid=94e79240-e11e-11e6-8443$\underline{00000 a a b 0 f 6 b \& a c d n a t=1485143394}$

Ricci Judith A and Becker Stan. (1996). "Risk factors for wasting and stunting among children inMetro Cebu, Philippines".

Roba, K. T. (2016). Nutritional status of lactating mothers and their children 6-23 months of age in pre-and post-harvest seasons in two agro-ecological zones of rural Ethiopia.

Senthilkumar, S. K., Chacko, T. V., \&Suvetha, K. (2018). Nutritional status assessment of children aged 0-5 years and its determinants in a tribal community of Coimbatore district. International Journal Of Community Medicine And Public Health, 5(7), 2835-2845.

Shaikh S, Mahalanabis D, Chatterjee S, Kurpad A V and Khaled M A (2003). "Lean body mass in preschool aged urban children in India: gender difference

Shrimpton, R., \&Kachondham, Y. (2003). Analysing the causes of child stunting in DPRK. New York: UNICEF. 
Sultan S (2014) Prevalence of stunting and thinness among school-age children of working and nonworking mothers in rural areas of Aligarh district. Indian J Basic Appl MedRe3, Suppl. 3, 51-7. Availablefrom: http://ijbamr.com/pdf/51-57.pdf

Teklehaymanot, A. (2015). Nutritional status of children 2-5 years old, its relation with cow milk consumption and other associated factors in Kilte awlaelo District east ern $z$ one Tigray, Ethiopia (Doctoral dissertation, Bahir Dar University).

UNICEF supported water trucking for internally displaced people @UNICEF/Ethiopia/201 8/Ayene.

UNICEF/WHO/World Bank Joint Child Malnutrition Estimates Key finding of the 2018 editionevalhelp@ unicef.orghttp://www.who.int/mediacentre/factsheets/fs178/en/

United Nations. Administrative Committee on Co-ordination. Sub-committee on Nutrition, International Food Policy Research Institute. (2000). 4th Report on the world nutritio situation: nutrition throughout the life cycle. United Nations, Administrat ive Committee on Coordination, Subcommittee on Nutrition.

United Nations Children's Fund (UNICEF) (2015). The State of the World's Children 2007 Women and Children. UNICEF, New York.

Veronicah, K., Kogi Makau, W., \& Muroki, N. M. (2007). The role of irrigation on improvement of nutritional status of young children in central Kenya. African Journal of Food, Agriculture, Nutrition and Development, 7(2), 1-16.

Vollmer, S., Bommer, C., Krishna, A., Harttgen, K., \& Subramanian, S. V. (2016). The association of parental education with childhood under nutrition in low-and middleincome countries: comparing the role of paternal and maternal education. International $j$ ournal of epidemiology, 46(1), 312-323.

Wessells, K. R., \& Brown, K. H. (2012). Estimating the global prevalence of zinc deficiency: results based on zinc availability in national food supplies and the prevalence of stunting. PloS one, 7(11), e50568. 
WHO(2011): Nutrition experts take action on malnutrition". World Health Organization"www.w ho.int/nutrition/pressnote_action_on_malnutrition/en/ Retrieved 12 May 2013.

WHO,2015 World Health Organization. Child growth standards: length/height-for-age. Geneva: World Health Organization; 2015 [cited 2015 Apr 8]. vailable from: http://www. who.int/childgrowth/standards/height_for_age/en/).

World Health Organization. (2017). The Partnership for Maternal, Newborn and Child Health 2016 annual report: coming of age in a time of transition (No.WHO/FWC/ NMC/ 7.1). World Health Organization.

Yoong, J., Rabinovich, L., \& Diepeveen, S. (2012). The impact of economic resource trans fers t o women versus men: a systematic review. Institute of Education technical report,Univer sity of London (London, EPPI-Centre).

Zaboli, R. (2017). Conceptual Models of Social Determinants of Health: A Narrative Review. Iran J Public Health, 46(4), 435-446.

Zottarelli, L. K., Sunil, T. S., \& Rajaram, S. (2007). Influence of parental and socioeconomic fact ors on stunting in children under 5 years in Egypt. 


\section{List of Figure}

Figure 1

Figure 2

\section{List of Tables}

Table1:

\begin{tabular}{|c|c|c|c|c|c|c|c|c|}
\hline \multirow[t]{2}{*}{ Variable } & \multirow[t]{2}{*}{ Category } & \multirow[t]{2}{*}{ Count } & \multirow[t]{2}{*}{$\%$} & \multicolumn{2}{|c|}{$\begin{array}{l}\text { Height for age status of the } \\
\text { child }\end{array}$} & \multirow[t]{2}{*}{ Df } & \multirow[t]{2}{*}{$\begin{array}{l}\text { chi- } \\
\text { square }\end{array}$} & \multirow[t]{2}{*}{$\begin{array}{l}\mathrm{p}- \\
\text { value }\end{array}$} \\
\hline & & & & Not stunted $\%$ & Stunted\% & & & \\
\hline \multirow{11}{*}{ Region } & Tigray & 855 & 9.9 & $443(51.8 \%)$ & $412(48.2 \%)$ & \multirow[t]{11}{*}{10} & \multirow[t]{11}{*}{308.79} & \multirow[t]{11}{*}{0.000} \\
\hline & Afar & 898 & 10.4 & $539(59.0 \%)$ & $359(41.0 \%)$ & & & \\
\hline & Amhara & 807 & 9.3 & $335(41.5 \%)$ & $472(58.5 \%)$ & & & \\
\hline & Oromiya & 1341 & 15.5 & $766(57.1 \%)$ & $575(42.9 \%)$ & & & \\
\hline & Somlia & 1110 & 12.8 & $469(42.3 \%)$ & $641(57.7 \%)$ & & & \\
\hline & Benshangul & 736 & 8.5 & $329(44.7 \%)$ & $407(55.3 \%)$ & & & \\
\hline & SNNPR & 970 & 11.2 & $545(56.2 \%)$ & $425(43.8 \%)$ & & & \\
\hline & Gambela & 570 & 6.6 & $350(61.4 \%)$ & $220(38.6 \%)$ & & & \\
\hline & Harari & 541 & 6.3 & $281(51.9 \%)$ & $260(48.1 \%)$ & & & \\
\hline & AdissAbeba & 348 & 4.0 & $294(84.5 \%)$ & $54(15.5 \%)$ & & & \\
\hline & Dire Dawa & 464 & 5.4 & $273(58.8 \%)$ & $191(41.2 \%)$ & & & \\
\hline \multirow[t]{3}{*}{ Family Size } & $1-4$ & 2482 & 28.7 & $1433(57.7 \%)$ & $1049(42.3 \%)$ & \multirow[t]{3}{*}{2} & \multirow[t]{3}{*}{43.613} & \multirow[t]{3}{*}{0.000} \\
\hline & $5-9$ & 5447 & 63.1 & $2868(52.7 \%)$ & $2579(47.3 \%)$ & & & \\
\hline & 10 and above & 711 & 8.2 & $315(44.3 \%)$ & $396(55.7 \%)$ & & & \\
\hline \multirow{5}{*}{ Age of Child } & 6-11 month & 1024 & 11.9 & $419(40.9 \%)$ & $605(59.1 \%)$ & \multirow[t]{5}{*}{4} & \multirow[t]{5}{*}{989.29} & \multirow[t]{5}{*}{0.000} \\
\hline & $12-23$ month & 1909 & 22.1 & $698(36.6 \%)$ & $1211(63.4 \%)$ & & & \\
\hline & $24-35$ month & 1870 & 21.6 & $901(48.2 \%)$ & $969(51.8 \%)$ & & & \\
\hline & 36-47 month & 1844 & 21.3 & $951(51.6 \%)$ & $893(48.4 \%)$ & & & \\
\hline & $48-59$ month & 1993 & 23.1 & $1647(82.6 \%)$ & $346(17.4 \%)$ & & & \\
\hline \multirow[t]{2}{*}{ Sex of child } & Male & 4602 & 53.3 & $1957(42.5 \%)$ & $2645(57.5 \%)$ & \multirow[t]{2}{*}{1} & \multirow[t]{2}{*}{64.880} & \multirow[t]{2}{*}{0.000} \\
\hline & Female & 4038 & 46.7 & $2067(51.2 \%)$ & $1971(48.8 \%)$ & & & \\
\hline \multirow{4}{*}{$\begin{array}{l}\text { Mother's } \\
\text { Education } \\
\text { attainment }\end{array}$} & No Education & 5414 & 62.7 & $2227(41.1)$ & $3187(58.9 \%)$ & 3 & 907.52 & 0.000 \\
\hline & Primary & 2393 & 27.7 & $1725(72.1 \%)$ & $668(27.9 \%)$ & & & \\
\hline & Secondary & 746 & 8.6 & $579(77.6 \%)$ & $167(22.4 \%)$ & & & \\
\hline & Higher & 87 & 1.0 & $85(97.7 \%)$ & $2(2.3 \%)$ & & & \\
\hline \multirow{3}{*}{$\begin{array}{l}\text { Father's } \\
\text { Education } \\
\text { attainment }\end{array}$} & No education & 4168 & 48.2 & $1557(37.4 \%)$ & $2611(62.6 \%)$ & \multirow[t]{3}{*}{3} & \multirow[t]{3}{*}{917.17} & 0.000 \\
\hline & Primary & 3097 & 35.8 & $2064(66.6 \%)$ & $1033(33.4 \%)$ & & & \\
\hline & Secondary & 1103 & 12.8 & $737(66.8 \%)$ & $366(33.2 \%)$ & & & \\
\hline
\end{tabular}




\begin{tabular}{|c|c|c|c|c|c|c|c|c|}
\hline & Higher & 272 & 3.1 & $258(94.9 \%)$ & $14(5.1 \%)$ & & & \\
\hline \multirow{2}{*}{$\begin{array}{l}\text { Place } \\
\text { residence }\end{array}$} & Urban & 1483 & 17.2 & $1092(73.9 \%)$ & $391(26.1 \%)$ & \multirow[t]{2}{*}{1} & \multirow[t]{2}{*}{7.762} & \multirow[t]{2}{*}{0.006} \\
\hline & Rural & 7157 & 82.8 & $3524(49.2 \%)$ & $3633(50.8 \%)$ & & & \\
\hline \multirow{2}{*}{$\begin{array}{l}\text { Mother's } \\
\text { working } \\
\text { status }\end{array}$} & Not working & 6174 & 71.5 & $3685(59.7 \%)$ & $2489(40.3 \%)$ & \multirow[t]{2}{*}{1} & \multirow[t]{2}{*}{340.65} & \multirow[t]{2}{*}{0.000} \\
\hline & Working & 2466 & 28.5 & $931(37.8 \%)$ & $1535(62.2 \%)$ & & & \\
\hline \multirow[t]{3}{*}{ Size at Birth } & $\begin{array}{l}\text { larger than } \\
\text { average }\end{array}$ & 2233 & 34.8 & $1265(56.7 \%)$ & $968(43.3 \%)$ & \multirow[t]{3}{*}{2} & \multirow[t]{3}{*}{22.016} & \multirow[t]{3}{*}{0.000} \\
\hline & Average & 3401 & 39.4 & $1840(54.1 \%)$ & $1561(45.9 \%)$ & & & \\
\hline & $\begin{array}{l}\text { smaller than } \\
\text { average }\end{array}$ & 3006 & 25.8 & $1511(50.3 \%)$ & $1495(49.7 \%)$ & & & \\
\hline \multirow{3}{*}{ BMI } & $<18.5$ (thin) & 2532 & 29.3. & $940(37.1 \%)$ & $1592(62.9 \%)$ & \multirow[t]{3}{*}{2} & \multirow[t]{3}{*}{386.93} & \multirow[t]{3}{*}{0.000} \\
\hline & $\begin{array}{l}\text { 18.5- } \\
24.9 \text { (Normal) }\end{array}$ & 4357 & 50.4 & $2585(59.3 \%)$ & $1772(40.7 \%)$ & & & \\
\hline & $\begin{array}{l}>=24.9 \text { (Overwe } \\
\text { ight) }\end{array}$ & 1751 & 20.3 & $1091(62.3 \%)$ & $660(37.7 \%)$ & & & \\
\hline \multirow[t]{3}{*}{ Wealth Index } & Poor & 4723 & 54.7 & $2221(47.0 \%)$ & $2502(53.0 \%)$ & \multirow[t]{3}{*}{2} & \multirow[t]{3}{*}{989.29} & \multirow[t]{3}{*}{0.039} \\
\hline & Middle & 2258 & 26.1 & $1182(52.3 \%)$ & $1076(47.7 \%)$ & & & \\
\hline & Rich & 1659 & 19.2 & $932(56.2 \%)$ & $727(43.8 \%)$ & & & \\
\hline \multirow{4}{*}{ Birth order } & 1 & 1706 & 19.7 & $1584(92.8 \%)$ & $122(7.2 \%)$ & \multirow[t]{4}{*}{3} & \multirow[t]{4}{*}{1971.8} & \multirow[t]{4}{*}{0.000} \\
\hline & $2-3$ & 2643 & 30.6 & $913(34.5 \%)$ & $1730(65.5 \%)$ & & & \\
\hline & $4-5$ & 2114 & 24.5 & $1409(66.7 \%)$ & $705(33.3 \%)$ & & & \\
\hline & $6+$ & 2177 & 25.2 & $710(32.6 \%)$ & $1467(67.4 \%)$ & & & \\
\hline \multirow{2}{*}{$\begin{array}{l}\text { Had diarrhea } \\
\text { in the last two } \\
\text { month }\end{array}$} & No & 7157 & 82.8 & $3975(55.5 \%)$ & $3182(44.5 \%)$ & \multirow[b]{2}{*}{1} & \multirow[b]{2}{*}{74.895} & \multirow[b]{2}{*}{0.000} \\
\hline & Yes & 1483 & 17.2 & $641(43.2 \%)$ & $842(56.8 \%)$ & & & \\
\hline \multirow{2}{*}{$\begin{array}{l}\text { Had Fever in } \\
\text { the last two } \\
\text { month }\end{array}$} & No & 7015 & 84.2 & $3535(69.9 \%)$ & $3480(49.6 \%)$ & \multirow{2}{*}{1} & \multirow{2}{*}{218.50} & \multirow{2}{*}{0.000} \\
\hline & Yes & 1625 & 18.8 & $490(30.1)$ & $1135(50.4 \%)$ & & & \\
\hline
\end{tabular}

Table 2:

\begin{tabular}{|c|c|l|l|l|}
\hline \multicolumn{1}{|c|}{ Model } & Coefficient & S.E & Z-value & P-value \\
\hline Fixed Intercept $\left(\beta_{0}\right)$ & 3.722 & 0.941 & 4.00 & 0.0043 \\
\hline $\begin{array}{l}\text { Random Intercept } \\
\operatorname{Var}\left(u_{0 j}\right)\end{array}$ & 212.516 & 38.381 & 5.54 & 0.0010 \\
\hline
\end{tabular}


Table 3:

\begin{tabular}{|c|c|c|c|c|c|c|}
\hline Covarities & Categories & Coef & Std. Err. & $\mathrm{Z}$ & $\mathrm{P}>\mathrm{Z}$ & $\begin{array}{l}\text { Odds } \\
\text { ratio }\end{array}$ \\
\hline & Constant & -5.77 & 1.203 & -4.79 & 0.000 & 0.0032 \\
\hline \multirow{4}{*}{$\begin{array}{l}\text { Mother education } \\
\text { level }\end{array}$} & No education(ref) & & & & & \\
\hline & Primary & -7.69 & 1.39 & -5.54 & 0.000 & 0.00045 \\
\hline & Secondary & -5.52 & 1.49 & -3.70 & 0.000 & 0.004 \\
\hline & Higher & -4.17 & 2.27 & -1.84 & 0.066 & 0.015 \\
\hline \multirow[t]{4}{*}{ Father education } & $\begin{array}{l}\text { No } \\
\text { education(Ref) }\end{array}$ & & & & & \\
\hline & Primary & -4.050 & 1.318 & -3.073 & 0.000 & 0.017 \\
\hline & Secondary & 1.405 & 3.986 & 0.352 & 0.267 & 4.075 \\
\hline & Higher & -0.692 & 4.329 & -0.159 & 0.402 & 0.50 \\
\hline \multirow[t]{3}{*}{ Family size } & $1-4(r e f)$ & & & & & \\
\hline & $5-9$ & -0.069 & 0.338 & -0.204 & 0.405 & 0.933 \\
\hline & 10 and above & -0.409 & 0.362 & -1.129 & 0.135 & 0.664 \\
\hline \multirow{3}{*}{ BMI } & $<18.5$ (ref) & & & & & \\
\hline & $18.5-24.9$ & -1.108 & 0.69 & -1.605 & 0.050 & 0.33 \\
\hline & $>=25$ & 1.007 & 0.71 & 1.418 & 0.071 & 2.734 \\
\hline \multirow{2}{*}{$\begin{array}{l}\text { Sex of } \\
\text { Child }\end{array}$} & Male(ref) & & & & & \\
\hline & Female & -1.387 & 0.175 & -7.93 & 0.000 & 0.249 \\
\hline \multirow{3}{*}{$\begin{array}{l}\text { Size of } \\
\text { Child at } \\
\text { Birth }\end{array}$} & $\begin{array}{l}\text { Larger than } \\
\text { Average(ref) }\end{array}$ & & & & & \\
\hline & Average & 0.881 & 0.601 & 1.466 & 0.100 & 2.413 \\
\hline & $\begin{array}{l}\text { Smaller than } \\
\text { Average }\end{array}$ & 3.17 & 2.78 & 7.032 & 0.000 & 23.801 \\
\hline \multirow{4}{*}{$\begin{array}{l}\text { Birth } \\
\text { order }\end{array}$} & 1(ref) & & & & & \\
\hline & $2-3$ & 4.799 & 0.433 & 11.083 & 0.000 & 121.38 \\
\hline & $4-5$ & 2.785 & 0.414 & 6.727 & 0.000 & 16.199 \\
\hline & $6+$ & 3.423 & 0.452 & 7.573 & 0.000 & 30.661 \\
\hline
\end{tabular}




\begin{tabular}{|c|c|c|c|c|c|c|}
\hline \multirow{2}{*}{$\begin{array}{l}\text { Mother } \\
\text { Working } \\
\text { status }\end{array}$} & Not Working(ref) & & & & & \\
\hline & Working & 4.038 & 0.669 & 6.035 & 0.000 & 56.712 \\
\hline \multirow{5}{*}{$\begin{array}{l}\text { Age of } \\
\text { children }\end{array}$} & 6-11(ref) & & & & & \\
\hline & $12-23$ & -3.038 & 1.336 & -2.273 & 0.000 & 0.048 \\
\hline & $24-36$ & -4.858 & 1.176 & -4.130 & 0.000 & 0.0077 \\
\hline & $37-46$ & -2.116 & 1.100 & -2.00 & 0.001 & 0.121 \\
\hline & $47-59$ & -4.580 & 1.195 & 3.833 & 0.000 & 0.010 \\
\hline \multirow{3}{*}{$\begin{array}{l}\text { Wealth } \\
\text { index }\end{array}$} & Poorest(ref) & & & & & \\
\hline & Middle & -1.168 & 0.232 & -5.034 & 0.000 & 0.311 \\
\hline & Rich & -0.943 & 0.267 & -3.532 & 0.001 & 0.389 \\
\hline \multirow{2}{*}{$\begin{array}{l}\text { Type of } \\
\text { Place of } \\
\text { Residenc } \\
\text { e }\end{array}$} & Urban(ref) & & & & & \\
\hline & Rural & 6.409 & 1.891 & 3.389 & 0.000 & 607.29 \\
\hline \multirow{2}{*}{$\begin{array}{l}\text { Had } \\
\text { Diarrhea } \\
\text { in the last } \\
\text { two } \\
\text { weeks }\end{array}$} & No(ref) & & & & & \\
\hline & Yes & 0.693 & 0.601 & 1.153 & 0.121 & 1.99 \\
\hline \multirow{2}{*}{$\begin{array}{l}\text { Had } \\
\text { Fever in } \\
\text { the last } \\
\text { two } \\
\text { weeks }\end{array}$} & No(ref) & & & & & \\
\hline & Yes & -0.297 & 3.940 & -0.075 & 0.390 & 0.743 \\
\hline Random effect & & Estimate & S.E & Z-val & P-va & \\
\hline Var-oij & & 149.20 & 35.96 & 4.15 & 0.002 & \\
\hline
\end{tabular}

Table 4:

\begin{tabular}{|l|l|l|l|l|l|l|}
\hline Covariates & Categories & Coef & Std. Err. & Z & P>Z & $\begin{array}{l}\text { Odds } \\
\text { ratio }\end{array}$ \\
\hline Mother education level & Constant & -1.585 & 1.324 & -1.197 & 0.121 & 0.205 \\
\cline { 2 - 7 } & $\begin{array}{l}\text { No } \\
\text { education(ref) }\end{array}$ & & & & & \\
\hline
\end{tabular}




\begin{tabular}{|c|c|c|c|c|c|c|}
\hline & Primary & -0.894 & 2.238 & -0.399 & 0.138 & 0.409 \\
\hline & Secondary & -1.282 & 0.198 & -6.475 & 0.000 & 0.2775 \\
\hline & Higher & -3.421 & 3.011 & -1.136 & 0.116 & 0.033 \\
\hline \multirow[t]{4}{*}{ Father education } & $\begin{array}{l}\text { No } \\
\text { education(Ref) }\end{array}$ & & & & & \\
\hline & Primary & -3.644 & 1.502 & -2.426 & 0.010 & 0.026 \\
\hline & Secondary & -4.232 & 2.712 & -1.560 & 0.060 & 0.015 \\
\hline & Higher & 6.397 & 3.913 & 1.634 & 0.246 & 600 \\
\hline \multirow{3}{*}{ Family size } & $1-4(\mathrm{ref})$ & & & & & \\
\hline & $5-9$ & -0.090 & 0.304 & -0.296 & 0.382 & 0.914 \\
\hline & 10 and above & -0.399 & 0.334 & -1.194 & 0.114 & 0.671 \\
\hline \multirow[t]{3}{*}{ BMI } & Thin $(<18.5)($ ref $)$ & & & & & \\
\hline & $\begin{array}{l}\text { Normal(18.5- } \\
24.9)\end{array}$ & -1.539 & 0.679 & $-' 2.665$ & 0.007 & 0.215 \\
\hline & $\begin{array}{l}\text { Overweight }(>=2 \\
\text { 5) }\end{array}$ & 0.589 & 0.680 & 0.866 & 0.203 & 1.802 \\
\hline \multirow[t]{2}{*}{ Sex of Child } & Male(ref) & & & & & \\
\hline & Female & -0.424 & 0.177 & -2.395 & 0.012 & 0.654 \\
\hline \multirow{2}{*}{$\begin{array}{l}\text { Had diarrhea in the last } \\
\text { two weeks }\end{array}$} & No(ref) & & & & & \\
\hline & Yes & 0.632 & 0.714 & 0.885 & 0.188 & 1.881 \\
\hline \multirow[t]{3}{*}{ Size of Child at Birth } & $\begin{array}{l}\text { Larger than } \\
\text { Average (ref) }\end{array}$ & & & & & \\
\hline & Average & 1.624 & 0.775 & -2.095 & 0.023 & 5.073 \\
\hline & $\begin{array}{l}\text { Smaller than } \\
\text { average }\end{array}$ & 0.584 & 0.049 & 11.92 & 0.000 & 1.793 \\
\hline \multirow{4}{*}{ Birth order } & 1(ref) & & & & & \\
\hline & $2-3$ & 4.689 & 0.380 & 12.34 & 0.000 & 108.74 \\
\hline & $4-5$ & 2.745 & 0.414 & 6.631 & 0.000 & 15.565 \\
\hline & $6+$ & 3.456 & 0.385 & 8.977 & 0.000 & 31.689 \\
\hline \multirow[t]{2}{*}{ Mother Working status } & Not working(ref) & & & & & \\
\hline & Working & 3.982 & 0.694 & 5.738 & 0.000 & 53.624 \\
\hline \multirow{5}{*}{ Age of children } & 6-11(ref) & & & & & \\
\hline & $12-23$ & 2.423 & 1.070 & -2.264 & 0.015 & 11.279 \\
\hline & $24-35$ & -3.485 & 1.175 & -2.966 & 0.012 & 0.031 \\
\hline & $36-47$ & -0.793 & 1.244 & -0.637 & 0.286 & 0.452 \\
\hline & $48-59$ & -3.125 & 1.310 & 2.385 & 0.000 & 0.044 \\
\hline \multirow[t]{2}{*}{ Wealth index } & Poorest(ref) & & & & & \\
\hline & Middle & -1.136 & 0.254 & -4.472 & 0.000 & 0.321 \\
\hline
\end{tabular}




\begin{tabular}{|l|l|l|l|l|l|l|}
\hline & Rich & -0.976 & 0.275 & -3.549 & 0.000 & 0.377 \\
\hline \multirow{2}{*}{$\begin{array}{l}\text { Had fever in the last two } \\
\text { weeks }\end{array}$} & No(ref) & & & & & \\
\cline { 2 - 7 } $\begin{array}{l}\text { Type of Place of } \\
\text { Residence }\end{array}$ & Yes & 0.538 & 1.761 & 0.305 & 0.108 & 1.713 \\
\hline Random effect & Rural & 1.093 & 0.508 & 2.152 & 0.005 & 2.983 \\
\hline $\operatorname{Var}\left(\mathrm{u}_{0 \mathrm{j}}\right)=\sigma_{\mathrm{u} 0 \mathrm{j}}^{2}$ & $\begin{array}{l}\text { Estimat } \\
\text { e }\end{array}$ & S.E & Z-val & P-va & \\
\hline $\operatorname{Var}\left(\mathrm{u}_{11 \mathrm{j}}\right)=\sigma_{\mathrm{u} 11 \mathrm{j}}^{2}$ & 93.732 & 16.28 & 5.757 & 0.000 & \\
\hline $\operatorname{Cov}\left(\mathrm{u}_{0 \mathrm{j}}, \mathrm{u}_{11 \mathrm{j}}\right)=\sigma_{\mathrm{u} 0 \mathrm{j}}^{2} \sigma_{\mathrm{u} 1 \mathrm{j}}^{2}$ & & 60.574 & 12.624 & 4.798 & 0.000 & \\
\hline
\end{tabular}

Table 5:

\begin{tabular}{|l|l|l|l|l|}
\hline Model & Dbar & D(thetabar) & PD & DIC \\
\hline Empty model & 1611.92 & 1464.19 & 147.73 & 1759.65 \\
\hline Random Intercept model & 1259.91 & 1094.0 & 165.90 & 1425.81 \\
\hline Random Coefficient model & 1246.88 & 1077.67 & 169.21 & 1416.09 \\
\hline
\end{tabular}




\section{Figures}

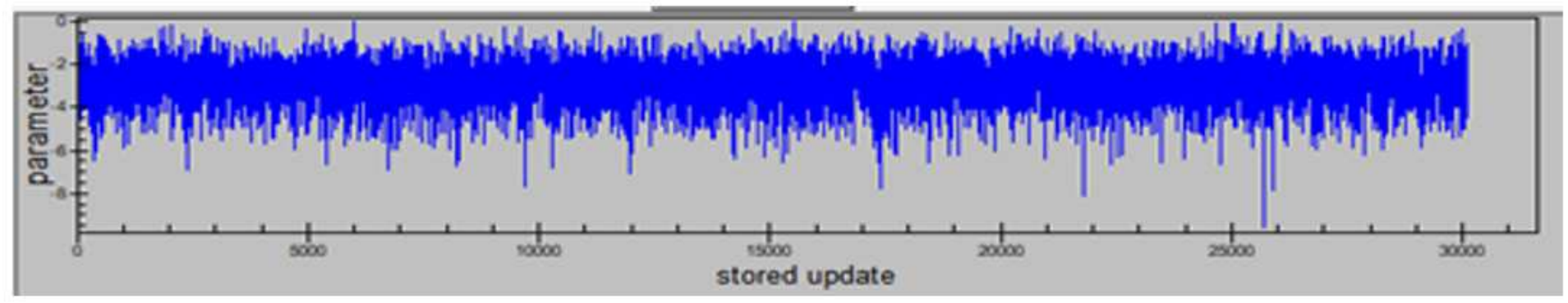

Figure 1

time series plot looks like horizontal band at 30,000 Iteration

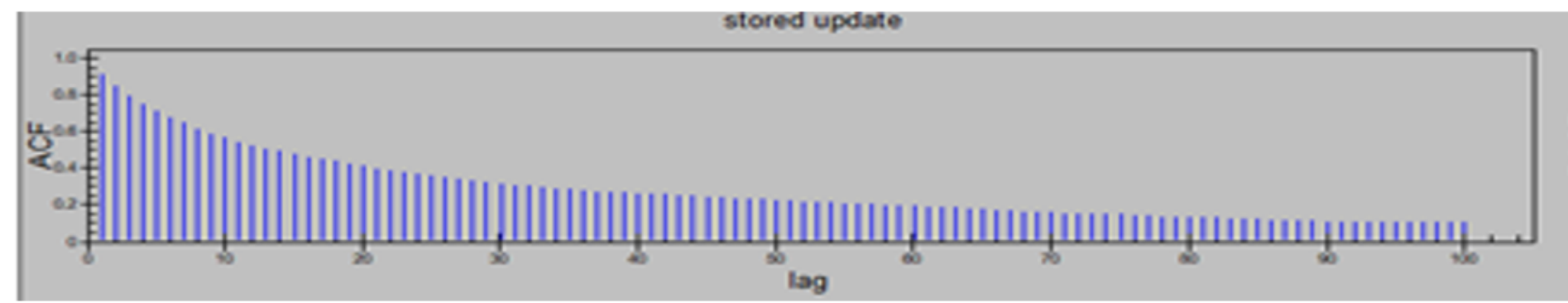

\section{Figure 2}

high convergence to posterior distribution on ACF

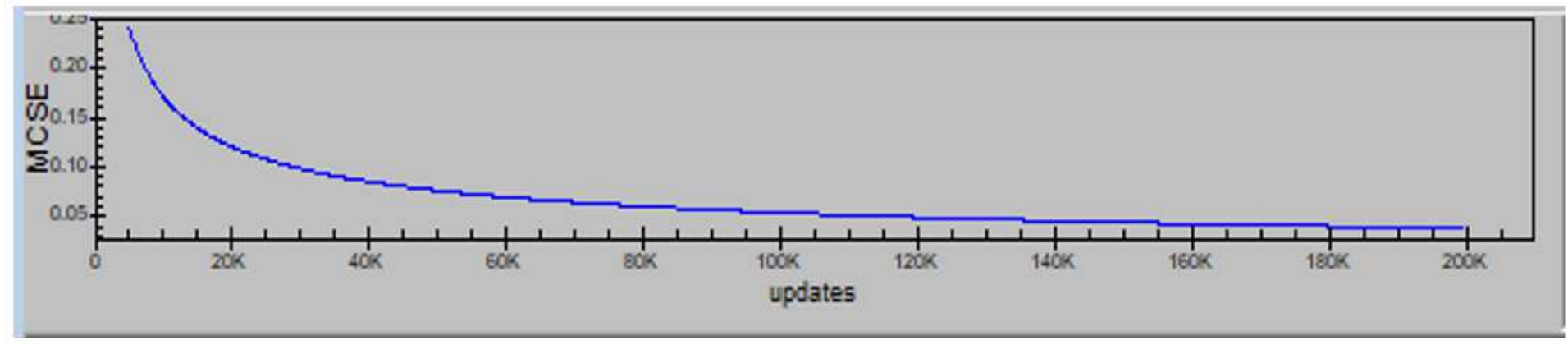

\section{Figure 3}

convergence

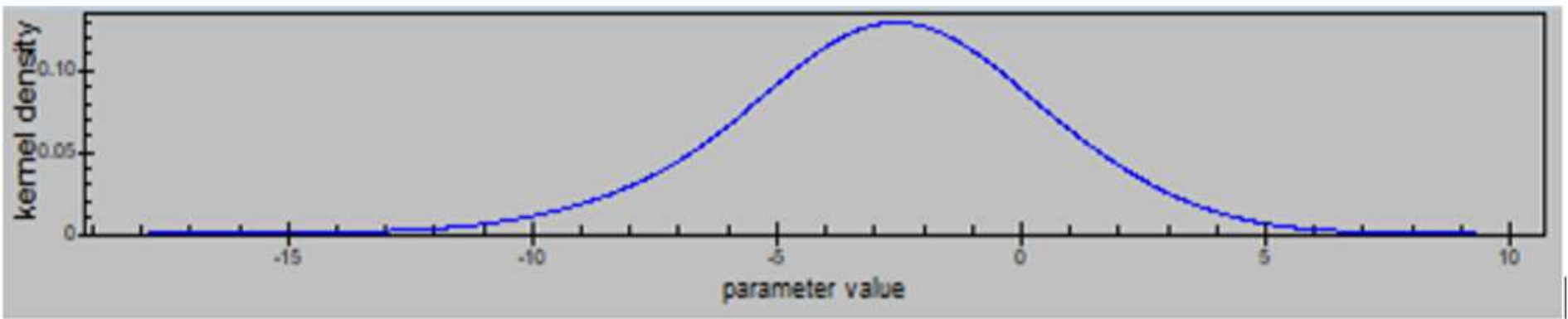


Figure 4

the coefficient has no bimodal density and it also shows convergence in the surveys

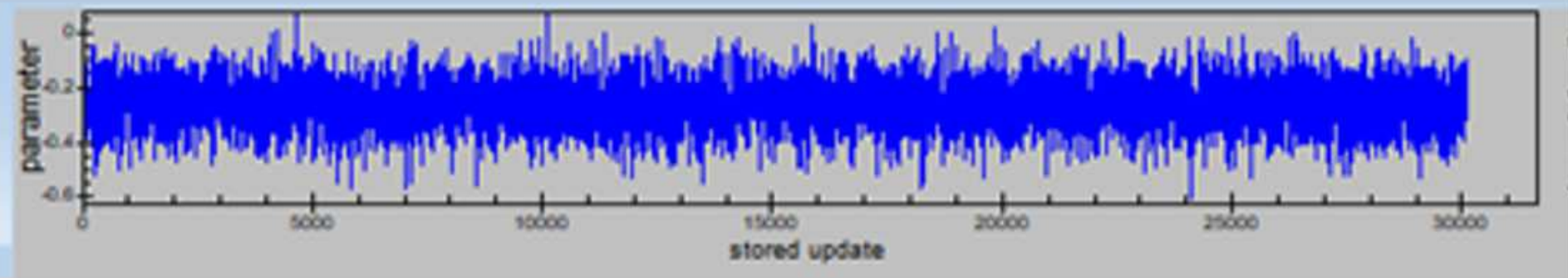

Figure 5

time series plot looks like horizontal band at 30,000 Iteration

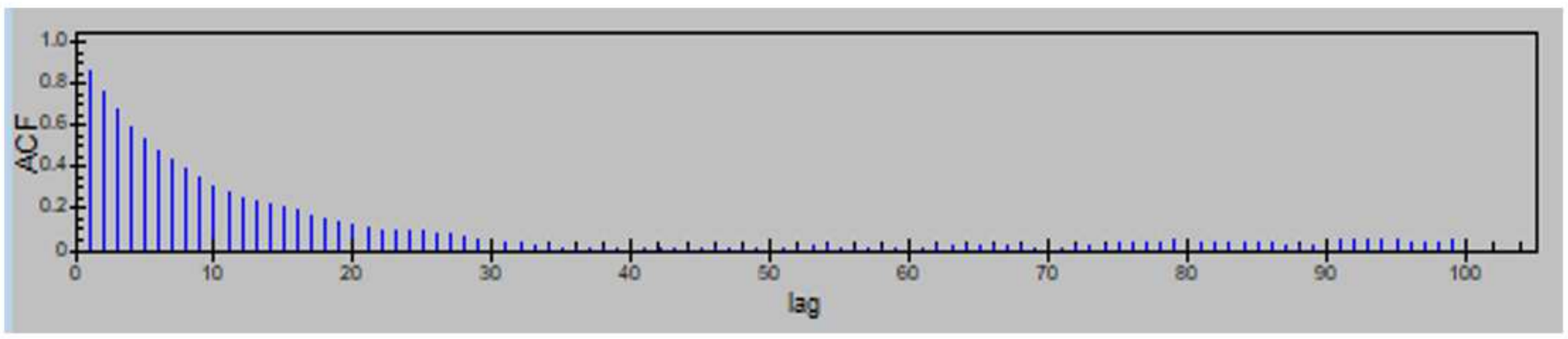

Figure 6

high convergence to posterior distribution on ACF

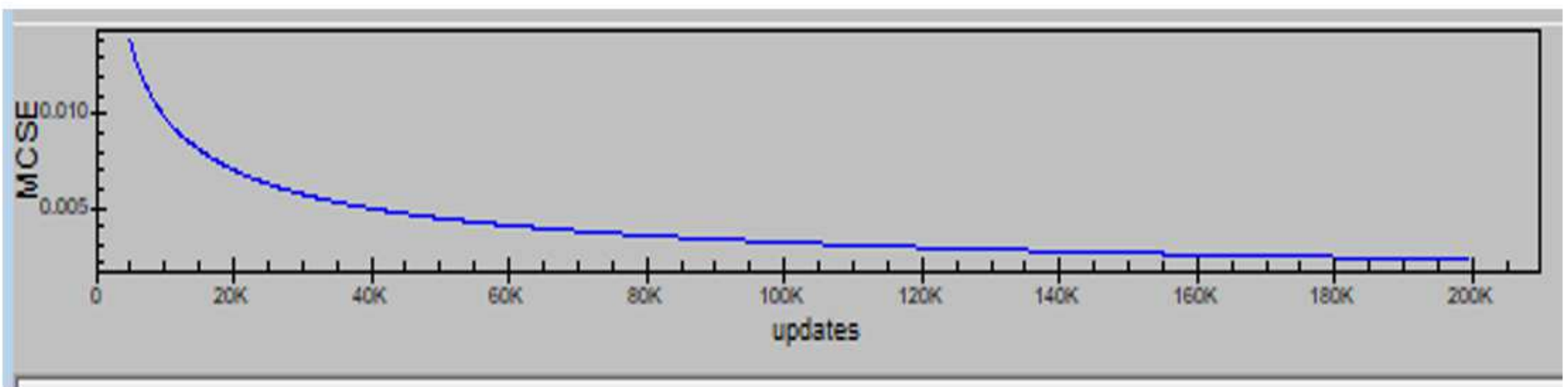

Figure 7

convergence 


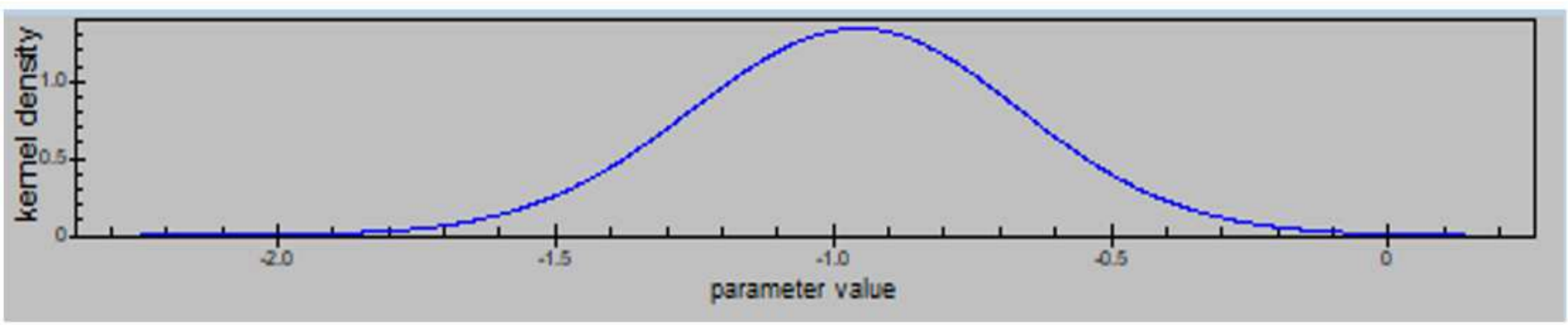

\section{Figure 8}

the coefficient has no bimodal density and it also shows convergence in the surveys 